\title{
Where Have the Monetary Surprises Gone? The Effects of FOMC Statements
}

Andrew Swiston 



\title{
IMF Working Paper
}

Western Hemisphere Department

Where Have the Monetary Surprises Gone? The Effects of FOMC Statements

Prepared by Andrew Swiston ${ }^{1}$

Authorized for distribution by Tamim Bayoumi

July 2007

\begin{abstract}
This Working Paper should not be reported as representing the views of the IMF. The views expressed in this Working Paper are those of the author(s) and do not necessarily represent those of the IMF or IMF policy. Working Papers describe research in progress by the author(s) and are published to elicit comments and to further debate.
\end{abstract}

This paper examines the impact of central bank communication on market expectations of monetary policy and long-term interest rates by comparing Federal Open Market Committee (FOMC) action dates when a policy statement was made to dates before statements were issued. Increased communication has been associated with a reduction in the magnitude of short-term monetary surprises; a greater flow of information about the long-term path of policy that is distinct from the short-term surprise; and a larger role for these long-term surprises in the determination of long-term interest rates.

JEL Classification Numbers: E43, E52, E58, E65, G14

Keywords: monetary policy, interest rates.

Author’s E-Mail Address: aswiston@imf.org

\footnotetext{
${ }^{1}$ This paper benefited from the helpful comments of Willem Thorbecke, Kornélia Krajnyák, and seminar participants at the IMF. All errors remain the author's.
} 


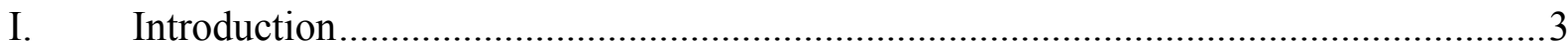

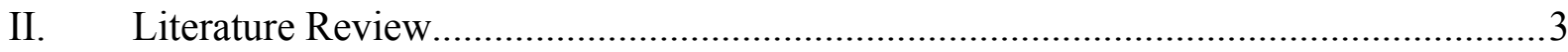

III. Information About Monetary Policy and Empirical Implications of Statements .......... 7

IV. Have Statements Made Short-Term Policy More Predictable? .................................9

V. Have Statements Provided Additional Information About the Future Path of Monetary Policy? ....................................................................................... 14

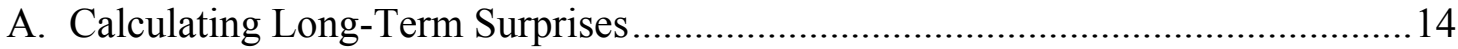

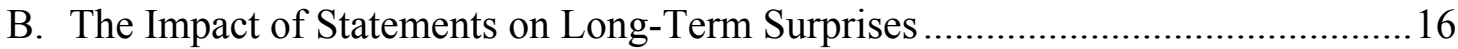

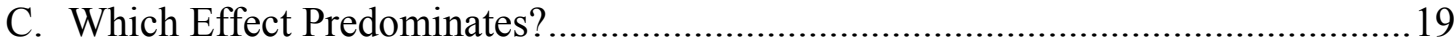

VI. Have Statements Led to an Increased Role for Long-Term Surprises in Explaining Interest Rate Movements?............................................................................2

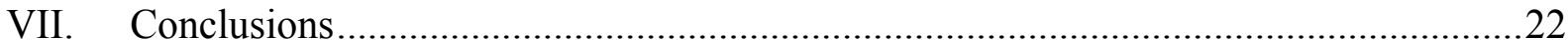

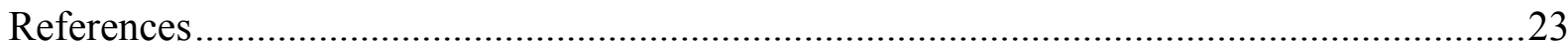

Figures

1. Current-Month Monetary Policy Surprises, July 1989-March 2007......................... 10

2. Long-Term Monetary Policy Surprises, July 1989-2007 ........................................ 17

Tables

1. Changes in the Federal Funds Rate and Treasury Yields .....................................

2. Monetary Policy Actions .................................................................................6

3. The Distribution of Daily Changes in Federal Funds Futures for the Current

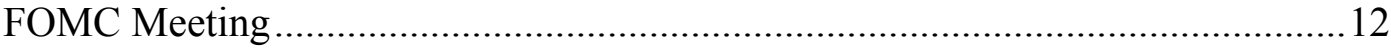

4. The Distribution of Daily Changes in the Expected Federal Funds Rate After the Next FOMC Meeting ................................................................................ 13

5. Correlation Between Changes in Current-Month Federal Funds and Four-Quarter Eurodollar Futures ................................................................................ 15

6. The Distribution of Daily Changes in Long-Term Monetary Surprises ...................... 18

7. The Distribution of Daily Changes in Four-Quarter Eurodollar Futures......................19

8. Policy Surprises and Treasury Yields Before February 1994 and

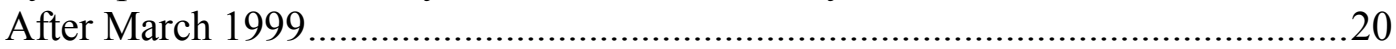

9. The Influence of Long-Term Surprises on Treasury Yields ...................................21 


\section{INTRODUCTION}

The central bank directly controls only one instrument, typically a short-term interest rate. Other interest rates and asset prices are tied to the path of this interest rate over time, so the transmission of monetary policy to the economy depends crucially on market expectations of the future path of policy. With the world's major central banks becoming increasingly transparent, communication plays a critical role in the formation of these expectations and the response of financial markets to monetary policy.

This paper examines the impact of a particular form of communication - the issuance of monetary policy statements by the U.S. Federal Open Market Committee (FOMC), which began in 1994 for FOMC meetings when the federal funds rate was changed and in May 1999 for all meetings. The effects of communication are identified by comparing financial market responses on policy dates when statements were made to episodes before statements were issued.

Statements have been associated with significant changes in the transmission of FOMC decisions to financial markets. First, surprises about the actual monetary policy decision have declined in magnitude, signifying that the information is incorporated into asset prices at an earlier stage. Second, changes in long-term interest rates on FOMC action dates have become less correlated with policy surprises. These developments suggest that statements have conveyed information unrelated to the current policy setting, and that their influence on longterm rates has been economically significant.

The rest of the paper is structured as follows: in Section II, the literature on monetary surprises is summarized and evidence is presented that some key findings of earlier work have weakened since the introduction of statements. The third section sets up a framework that models the transmission of information contained in statements to the prices of financial assets and describes the empirical implications that should result. Section IV looks at the effects of statements on short-term monetary surprises, while section V estimates a measure of long-term monetary surprises and shows how these have changed since the introduction of statements. Section VI shows the impact of both short-term and long-term monetary surprises on market interest rates of all horizons, and Section VII concludes.

\section{LITERATURE REVIEW}

Cook and Hahn (1989) first documented the connection between the federal funds rate and market interest rates by showing that, over the 1974-1979 period, changes in the federal funds rate had a significant impact on the yields of U.S. Treasury securities at all maturities. The results obtained by Cook and Hahn were partly because they analyzed a period when interest rate decisions were less systematized and transparent. In recent decades, market anticipation of monetary policy has improved. Thus, some of the potential impact of a target rate change would have already been incorporated into asset prices by the time the decision was made, causing the response to the actual event to diminish (Roley and Sellon, 1995). 


\begin{tabular}{|c|c|c|c|c|c|c|c|c|c|c|}
\hline \multirow[b]{3}{*}{ Maturity } & \multicolumn{4}{|c|}{ Raw target change } & \multicolumn{6}{|c|}{ Surprise vs. expected } \\
\hline & \multicolumn{2}{|c|}{$\begin{array}{l}\text { June, } 1989 \text { to } \\
\text { February, } 2000\end{array}$} & \multicolumn{2}{|c|}{$\begin{array}{l}\text { March, } 2000 \text { to } \\
\text { June, } 2006\end{array}$} & \multicolumn{3}{|c|}{$\begin{array}{c}\text { June, } 1989 \text { to February, } \\
2000\end{array}$} & \multicolumn{3}{|c|}{ March, 2000 to June, 2006} \\
\hline & $\Delta \mathrm{FFR}$ & $\mathrm{R}^{2}$ & $\Delta \mathrm{FFR}$ & $\mathrm{R}^{2}$ & Surprise & Expected & $\mathrm{R}^{2}$ & Surprise & Expected & $\mathrm{R}^{2}$ \\
\hline 3 month & $\begin{array}{l}26.8^{* *} \\
(4.0)\end{array}$ & 0.41 & $\begin{array}{l}12.0^{* *} \\
(3.4)\end{array}$ & 0.36 & $\begin{array}{l}81.5^{* *} \\
(12.3)\end{array}$ & $\begin{array}{r}3.3 \\
(4.5)\end{array}$ & 0.72 & $\begin{array}{l}56.2^{* *} \\
(11.4)\end{array}$ & $\begin{array}{l}6.4^{* *} \\
(1.9)\end{array}$ & 0.79 \\
\hline 6 month & $\begin{array}{l}21.9^{* *} \\
(3.9)\end{array}$ & 0.35 & $\begin{array}{l}11.1^{* *} \\
(2.9)\end{array}$ & 0.34 & $\begin{array}{l}73.0^{* *} \\
(9.7)\end{array}$ & $\begin{array}{r}-0.1 \\
(4.4)\end{array}$ & 0.70 & $\begin{array}{l}49.4^{* *} \\
(8.5)\end{array}$ & $\begin{array}{l}6.2 \\
(2.5)\end{array}$ & 0.71 \\
\hline 12 month & $\begin{array}{l}19.8^{* *} \\
(4.9)\end{array}$ & 0.28 & $\begin{array}{l}7.0^{*} \\
(3.2)\end{array}$ & 0.12 & $7^{72.7^{* *}}$ & $\begin{array}{r}-2.9 \\
(5.0)\end{array}$ & 0.65 & $\begin{array}{l}43.5^{* *} \\
(9.4)\end{array}$ & $\begin{array}{r}2.3 \\
(3.3)\end{array}$ & 0.45 \\
\hline 2 year & $\begin{array}{l}18.2^{* *} \\
(5.0)\end{array}$ & 0.24 & $\begin{array}{l}9.2 \\
(4.0)\end{array}$ & 0.12 & $\begin{array}{l}61.3^{* *} \\
(9.3)\end{array}$ & $\begin{array}{l}-0.4 \\
(6.2)\end{array}$ & 0.49 & $\begin{array}{l}45.3^{* *} \\
(14.5)\end{array}$ & $\begin{array}{r}4.6 \\
(4.9)\end{array}$ & 0.29 \\
\hline 5 year & $\begin{array}{l}10.4 \\
(5.6)\end{array}$ & 0.08 & $\begin{array}{r}4.8 \\
(4.0)\end{array}$ & 0.01 & $\begin{array}{l}48.1^{* *} \\
(10.6)\end{array}$ & $\begin{array}{l}-5.7 \\
(6.3)\end{array}$ & 0.29 & $\begin{array}{r}27.3 \\
(14.7)\end{array}$ & $\begin{array}{r}2.0 \\
(5.2)\end{array}$ & 0.07 \\
\hline 10 year & $\begin{array}{r}4.3 \\
(5.1)\end{array}$ & 0.00 & $\begin{array}{r}2.5 \\
(3.1)\end{array}$ & -0.01 & $\begin{array}{l}31.5 \\
(9.8)\end{array}$ & $\begin{array}{l}-7.4 \\
(5.6)\end{array}$ & 0.15 & $\begin{array}{r}21.7 \\
(11.3)\end{array}$ & $\begin{array}{r}0.1 \\
(4.3)\end{array}$ & 0.06 \\
\hline 30 year & $\begin{array}{r}0.1 \\
(4.2)\end{array}$ & -0.02 & $\begin{array}{l}-0.6 \\
(2.6)\end{array}$ & -0.03 & $\begin{array}{l}19.5 * \\
(8.1)\end{array}$ & $\begin{array}{r}-8.2 \\
(4.7)\end{array}$ & 0.09 & $\begin{array}{r}6.0 \\
(11.0)\end{array}$ & $\begin{array}{l}-1.5 \\
(3.7)\end{array}$ & -0.05 \\
\hline
\end{tabular}

Kuttner (2001) showed that Treasury yields did not respond at all to changes in the federal funds rate that were already anticipated, while there was still a large and significant impact of the unanticipated component of the interest rate announcement. He used federal funds futures contracts to measure market expectations of monetary policy in an event study framework, and several authors have followed, using similar approaches to assess the impact of monetary policy on bond yields and on the prices of other assets. ${ }^{2}$

The response of Treasury yields to the surprise component of interest rate changes has declined since the period covered by Kuttner (2001), as shown in Table $1 .{ }^{34}$ The results on the right-hand side show that the strongest impact of monetary surprises is still on short-term

\footnotetext{
${ }^{2}$ See, for example, Poole and Rasche (2000), Faust, Swanson, and Wright (2004), and Rigobon and Sack (2004) on the impact of monetary policy surprises on interest rates; Bernanke and Kuttner (2005), Bomfim (2003), and Rigobon and Sack (2004) on stock prices, Fatum and Scholnick (2006) on exchange rates, and Faust et al (2007) on foreign interest rates.

${ }^{3}$ The post-Kuttner sample corresponds roughly to the period in which statements were issued with every FOMC action; the results are similar when that sample is used.

${ }^{4}$ This table excludes September 17, 2001, when the federal funds rate was cut 50 basis points in response to the terrorist attacks on September 11; and January 3, 2001, when a surprise intermeeting move buoyed the markets so much that yields on securities of two years and longer rose significantly. Including either meeting would bias the results against finding an impact similar to that found by Kuttner.
} 
yields, with those coefficients ranging from $2 / 3$ to $3 / 4$ the size for the period through February 2000. The impact on longer-term yields has fallen by a larger fraction and is no longer statistically significant. The left-hand side of the table presents results for the methodology of Cook and Hahn (1989), and documents a continued deterioration in the response of yields to raw changes in the federal funds rate, as a higher proportion of actions have been anticipated by financial markets.

This decline in the response of long-term Treasury yields to FOMC surprises has a simple explanation: the advent of statements has reduced the importance of short-term monetary surprises used in studies like Kuttner's. At the same time, statements have increased the amount of information directly relevant to long-term yields. Since the surprise element of the statement is not necessarily correlated with the short-term surprise, longer-term yields do not move as frequently in the same direction as the short-term surprise. This explains both the lower response of long-term yields to the current surprise and their larger standard errors. ${ }^{5}$

Because of the diminished importance of current policy surprises, some authors have turned to analyzing the impact of longer-term surprises on asset prices. Gürkaynak, Sack, and Swanson (2005) use interest rate futures out to one year to decompose the financial market's response to FOMC actions into two components - the target factor, which corresponds closely to the current surprise, and the path factor, which incorporates all other information from the interest rate futures that does not affect the current setting of rates. They find that the path factor is closely associated with the occurrence of FOMC statements and that it explains a far greater share of the variation in long-term interest rates than does the target factor. Gürkaynak (2005) uses federal funds futures to calculate market expectations of interest rates for the next three FOMC meetings, then estimates a timing, level, and slope component to each surprise, related to the revision in expected rates for each of the three meetings. Although statements are not analyzed explicitly, his paper shows that long-term yields are much more sensitive to changes in expectations that persist at least through the next FOMC meeting.

Kohn and Sack (2003) and Bernanke, Reinhart, and Sack (2004) show that FOMC statements increase the variance of changes in interest rates and asset prices, relative to FOMC dates when no statement was issued. Kohn and Sack compare the share of variance in asset returns accounted for by the current policy surprise to that of a residual proxying for statements, and show that the longer the horizon of the security, the greater is the importance of the residual. In an approach similar to Gürkaynak, Sack, and Swanson (2005), Bernanke, Reinhart, and Sack decompose monetary policy surprises into three factors. They link statements to increased volatility in the second factor, which represents market expectations of interest

\footnotetext{
${ }^{5}$ The slightly lower number of observations since 2000 could be one factor behind the larger standard errors, but this explanation does not account for the fact that the standard errors for yields on securities at maturities of one year or less are about the same pre- and post-2000.
} 
rates one year ahead, and they show that there is a positive relationship between this factor and surprises in statements.

This paper measures the impact of FOMC statements on the magnitude of short- and longterm monetary surprises and on the relative importance of each type of surprise in the response of Treasury yields to FOMC decisions. Consistent with other analysis (Lange, Sack, and Whitesell, 2003; Poole, Rasche, and Thornton, 2002; and Swanson, 2006), short-term surprises are found to have declined, though other papers have not tied this phenomenon directly to the issuance of statements. Similarly, while previous authors' finding of an increase in the variance of long-term surprises is confirmed, this paper addresses the issue of composition bias in the comparison of surprises across time periods.

All of the papers examining the impact of longer-term expectations of monetary policy compare the impact of all FOMC actions with statements to all actions without statements, despite a significant difference in the composition of the two groups. First, few rate changes before 1994 took place on the days of scheduled FOMC meetings - it was much more common to change rates between meetings. Second, statements were issued only on rate change days from 1994 through $1998 .{ }^{6}$ Because of these occurrences, the share of dates when rates were changed is much higher during the period with statements (Table 2). The dispersion of market expectations, and the possibility of surprise, is greater when the federal funds rate is changing than during times of relative stability, so the difference in the makeup of the two groups could lead one to erroneously find an increase in the size of long-

\begin{tabular}{|c|c|c|}
\hline \multicolumn{3}{|c|}{$\begin{array}{l}\text { Table 2. Monetary Policy Actions } \\
\text { (percent of action dates) }\end{array}$} \\
\hline & Rate change & No change \\
\hline Statement (Feb. 1994-Mar. 2007) & 61 & 39 \\
\hline No statement (Jul. 1989-Mar. 1999) & 27 & 73 \\
\hline Jul. 1989-Dec. 1993 (no statement) & 43 & 57 \\
\hline May 1999-Mar. 2007 (statement) & 53 & 47 \\
\hline
\end{tabular}
term surprises. Because of this possible bias, this paper breaks down the results by the type of action that occurred-for example, looking at rate change days before and after the issuance of statements. Where all FOMC actions are considered together, the period from May 1999 to the present is compared to July 1989-December 1993, as the proportion of rate changes across the two samples is similar.

\footnotetext{
${ }^{6}$ Kohn and Sack (2003) also include eight days before 1994 when the discount rate was changed and the market correctly inferred that the target federal funds rate had changed as well. These pre-1994 statements merely announced the new discount rate and gave no forward-looking information, making those rate changes much more similar to other pre-1994 rate changes than to the kind of statement that was released from May 1999 onward. This paper follows other authors in not considering these dates to have contained a monetary policy statement.
} 


\section{Information About Monetary Policy AND EMPIRICAL IMPliCATIONS OF STATEMENTS}

This section explains the rationale behind the use of the event study methodology, sets up a theoretical framework to justify the decomposition of monetary policy surprises into shortand long-term elements, and outlines some empirical implications of the introduction of statements. As explained in Rigobon and Sack $(2003,2004)$, the typical problem encountered in estimating the response of asset prices to monetary policy is in establishing causality, since monetary policy can just as easily respond to movements in asset prices in order to offset their potential impact on the economy. The event study methodology attempts to circumvent the identification problem by isolating those instances in which monetary policy was clearly the dominant source of news affecting asset prices in the time window under consideration. Consider the following equation:

$\Delta i_{t}=\alpha+\beta \Delta m_{t}+\gamma z_{t}+\varepsilon_{t}$

where $\Delta i_{t}$ is the change in market interest rates, $\Delta m_{t}$ represents new information about monetary policy, and $z_{t}$ is a vector representing all other information that affects the interest rate of a particular maturity. In narrowing down the time frame under analysis to the days of FOMC meetings and federal funds rate changes, the event study methodology proceeds under the assumption that the variance in $m_{t}$ swamps that of $z_{t}$, so that the impact of other information on the asset price can be ignored.?

Analyzing the flow of information about monetary policy according to the time horizon with which the information deals is akin to breaking down $m_{t}$ in equation (1). For instance:

$$
\Delta m_{t}=f\left(s_{t}, l_{t}\right)
$$

In the framework used by Gürkaynak, Sack, and Swanson (2005), for example, $s_{t}$ represents all information that affects the current target interest rate and $l_{t}$ captures all other information that affects monetary policy expectations out to one year that does not affect the current target rate. ${ }^{8}$ These represent two separate factors of monetary policy expectations and are allowed to have different effects on market interest rates. Re-writing equation (1) using the terms in equation (2) yields:

$$
\Delta i_{t}=\alpha+\beta_{1} s_{t}+\beta_{2} l_{t}+\gamma z_{t}+\varepsilon_{t}
$$

\footnotetext{
${ }^{7}$ This identification scheme also minimizes any feedback effects from $z_{t}$ to $m_{t}$, as noted by Rigobon and Sack $(2003,2004)$.

${ }^{8}$ As these authors and others have stressed, this is only one of many possible deconstructions of the information transmitted about monetary policy, although they find that two factors are sufficient to describe the response of financial markets to information about monetary policy out to a one year horizon.
} 
Following from equations (2) and (3), the issuance of statements should have several empirical implications:

- $\quad$ The variance of long-term monetary surprises, $l_{t}$, should increase. The issuance of statements allows the FOMC to convey information about the possible future direction of policy, opening up a channel to directly affect $l_{t}$. On FOMC dates prior to 1999 , the Fed had to rely largely on changing current monetary conditions to affect long-term expectations. ${ }^{9}$ Presumably, a surprise change in the current target rate will have an impact on the market's expectations of the rate prevailing in the future, as shocks tend to be highly correlated (Rudebusch 2002, 2006). However, this should be seen as part of the impact of $s_{t}$ on $i_{t}$ in equation (3), and not as an element of $l_{t}$. Actual realizations of $l_{t}$, then, are likely to have grown in magnitude with statements.

- In a related point, a lower share of the variance in long-term monetary surprises should occur outside of FOMC days. With larger long-term shocks on FOMC days, the importance of non-FOMC days in explaining the variance in long-term monetary policy expectations should go down.

- $\quad$ The variance of short-term monetary surprises, $s_{t}$, should decline. If markets incorporate information about future policy actions in advance of the actual decision, that reduces the surprise element of the action itself.

- $\quad$ Also, a higher proportion of the variance in short-term monetary surprises should occur outside of FOMC days. Since the magnitude of short-term shocks attributed to policy dates decreases, economic developments on non-FOMC days would be expected to explain a greater share of the variability in measures of short-term monetary policy expectations.

- $\quad$ Long-term monetary surprises should take on a greater role in explaining long-term interest rates, with a reduced role for short-term monetary surprises. While the first point emphasizes movements in $l_{t}$, which would be uncorrelated with $s_{t}$, here the focus is on financial market instruments that are affected by both $l_{t}$ and $s_{t}$. Given the increased variability in $l_{t}$ and the reduced variability in $s_{t}, l_{t}$ should explain a greater share of the variance of long-term market interest rates, while the importance of movements in $s_{t}$ for long-term rates should fall. A statement should allow the FOMC to draw a distinction between current policy moves and the future outlook, when conditions warrant. Also, the increase in information about the long-term policy

\footnotetext{
${ }^{9}$ On the dates of FOMC meetings before 1994, there was no official information conveyed about monetary policy outside of the rate decision itself. The Fed could have affected long-term expectations on other dates, through speeches and Congressional testimony, for example, but these have not typically occurred near FOMC dates.
} 
outlook might better anchor expectations, which could make markets less likely to extrapolate forward current surprises $-S_{t}$-into long-term interest rates.

The following sections find evidence that all these effects have been present, pointing to the importance of FOMC statements in shaping market expectations of future monetary policy actions.

\section{Have Statements Made Short-Term Policy More Predictable?}

One of the hypothesized effects of FOMC statements is that short-term monetary surprises should decline. If statements reveal more information about long-term monetary policy by explaining the FOMC's view of current economic conditions and the outlook, then there should typically be less new information to reveal about policy at a short horizon. Also, a statement could make clear that the particular course of action depends upon economic outcomes unfolding in line with expectations. Thus, short-term surprises should decline even in the presence of shocks as the market changes its expectations of policy in response to the shock, leaving fewer surprises for FOMC days. Indeed, Bernanke, Reinhart, and Sack (2004) point out that the FOMC has frequently used conditional language in its statements, and, using data on payroll employment, present evidence that, when a certain category of economic data is emphasized in the statement, financial markets have a heightened response to those data releases.

This paper uses the daily change in the current-month federal funds futures contract to measure the current policy surprise, which, as noted, has become common in the literature. ${ }^{10}$ The contract refers to the average federal funds rate throughout the month, so the change in the futures rate on a given day equals the change in the expected federal funds target multiplied by the fraction of the month that the new rate is expected to prevail. Therefore, the daily change in the rate implied by the futures contract needs to be scaled up to extract the actual change in the expected federal funds rate, as in the below equation:

$$
s_{t}=\left(f_{t}^{0}-f_{t-1}^{0}\right) * \frac{D^{0}}{D^{0}-d^{0}}
$$

where $f_{t}^{0}$ is the federal funds futures rate for the current meeting, $D^{0}$ is the number of days in the month, and $d^{0}$ represents the number of days affected by the change in expectations.

\footnotetext{
${ }^{10}$ Krueger and Kuttner (1996), Gürkaynak, Sack, and Swanson (2006), and Hamilton (2007) show that federal funds futures contracts are good predictors of the federal funds rate. Piazzesi and Swanson (2006) and Sack (2004) document the existence of risk premiums on federal funds futures contracts, but Piazzesi and Swanson find that the time variation occurs mostly at business cycle frequencies and differencing the data cancels it out at high frequencies, while Sack's estimates indicate that the risk premium is small at short horizons. Hamilton (2007), however, shows that the finding of a risk premium is strongly influenced by a few outliers.
} 
Figure 1. Current-Month Monetary Policy Surprises, July 1989-March 2007
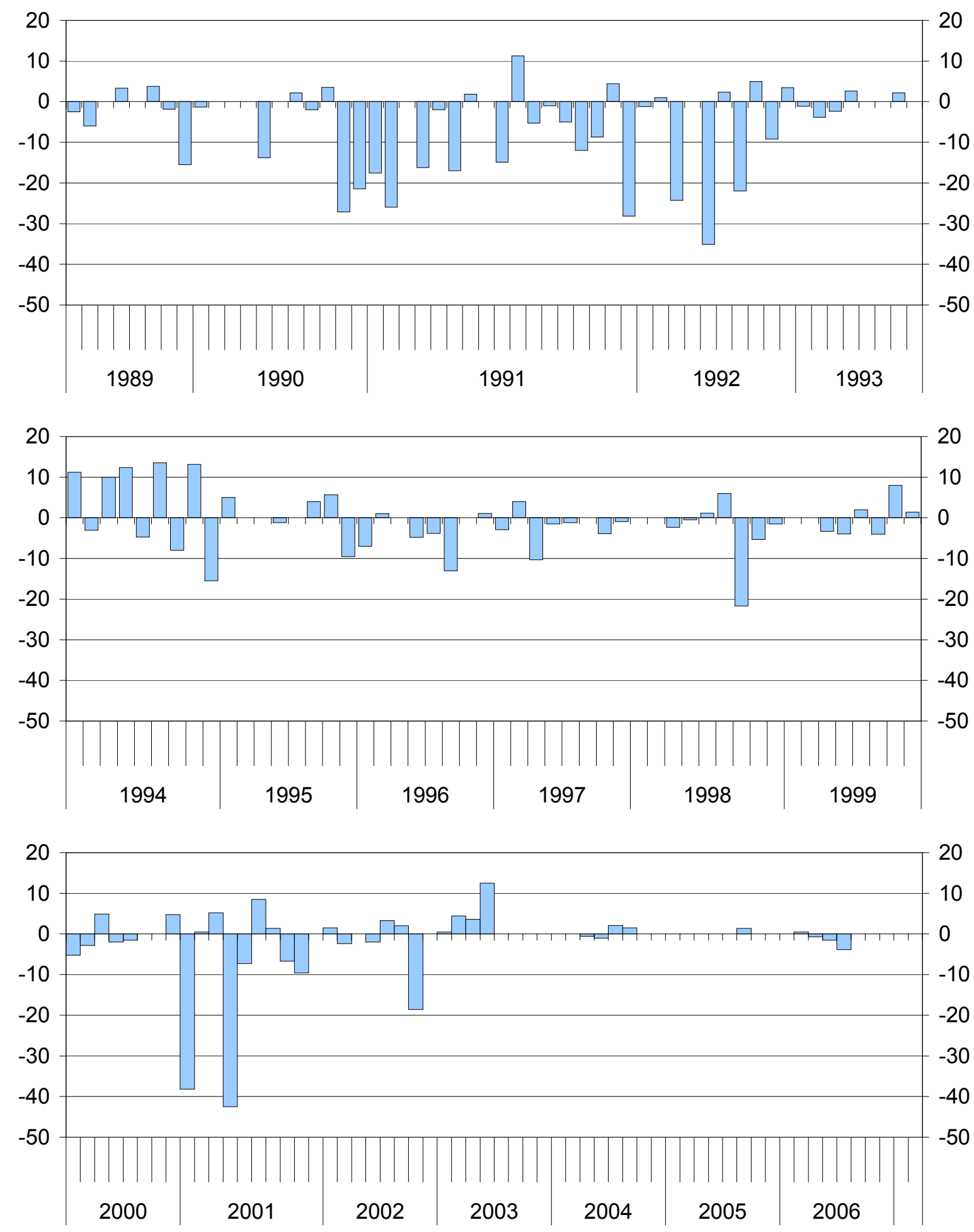

Source: IMF staff calculations. 
For policy dates in the last week of the month, the unscaled change in the following month's contract is used, as is standard in the literature. This avoids magnifying bid-ask spreads by multiplying by a large scale factor,. ${ }^{11}$ The sample runs from July 1989 to March 2007, and is determined by the availability of data. Since policy changes before 1994 were not announced to markets but inferred by the direction and scale of the Fed's open market operations, the timing of policy announcements follows the chronology in Kuttner (2001).

As seen in Figure 1, the magnitude of short-term policy surprises has declined since May 1999, with the difference particularly pronounced since mid-2003. All surprises since then have been within \pm 5 basis points. The largest surprises in the era of statements were on the days of intermeeting rate changes-January 3, 2001 and April 18, 2001. ${ }^{12}$ This suggests that financial market participants had grown accustomed to seeing the federal funds rate changed only at FOMC meetings, as there had been only one intermeeting move from 1995-2000.

Table 3 shows that both rate change days and inaction days have contributed to a decline in the volatility of short-term surprises. In order to analyze whether the two intermeeting rate cuts influence the results, there is a separate column showing the calculations excluding those dates and the two largest outliers from the pre-statement period. To assess the statistical significance of the change in variance, the table shows results of the Brown-Forsythe (1974) test on the distribution of independent variables. The findings include:

- Volatility has fallen even on non-action days. A clear interpretation is that the ex ante revelation of information about future policy actions - whether directly through a policy tilt, or indirectly through the Fed's assessment of economic conditions-has more firmly anchored short-term policy expectations. Swanson (2006) disproves the competing explanation that the economy has become more predictable over this period, as private sector forecasts for GDP and inflation have shown no such gains in accuracy.

- $\quad$ Surprises have also decreased on inaction days. The Fed has not used its statement to make major changes to short-term policy expectations on days when it has held rates unchanged. This is intuitive, since, if the Fed were to be certain enough that a change in direction were needed in the short-term, it would likely change rates immediately. Typically, when the current setting of rates is appropriate, at least a portion of upcoming changes have been signaled well in advance. The January 28, 2004 removal from the statement of the phrase "...policy accommodation can be

\footnotetext{
${ }^{11}$ See Kuttner (2001) or Gürkaynak (2005) for further details on the calculations.

${ }^{12}$ The 50 basis points rate cut on September 17, 2001 is excluded from all analysis as financial markets were affected by the September 11 terrorist attacks. All dates from the $11^{\text {th }}$ through the $17^{\text {th }}$ are excluded in the analysis of daily data.
} 


\begin{tabular}{|c|c|c|c|c|}
\hline \multicolumn{5}{|c|}{$\begin{array}{l}\text { Table 3. The Distribution of Daily Changes in } \\
\text { Federal Funds Futures for the Current FOMC Meeting }\end{array}$} \\
\hline & \multirow[t]{2}{*}{ Non-action } & \multicolumn{2}{|c|}{ Rate change } & \multirow{2}{*}{ Inaction } \\
\hline & & All & $\begin{array}{l}\text { Excluding two } \\
\text { largest } \\
\text { outliers } 1 /\end{array}$ & \\
\hline \multicolumn{5}{|l|}{ Variance (in basis points) } \\
\hline No statement & 16.93 & 116.38 & 91.14 & 17.20 \\
\hline Statement $2 /$ & 4.73 & 116.61 & 52.27 & 4.43 \\
\hline \multicolumn{5}{|c|}{ Significance of change in variance } \\
\hline P-value of Brown-Forsythe tests & 0.00 & 0.23 & 0.03 & 0.08 \\
\hline \multicolumn{5}{|c|}{ Impact of FOMC actions on variance } \\
\hline No statement & - & 272.62 & 198.93 & -18.77 \\
\hline Standard error & -- & $(67.42)$ & $(53.46)$ & $(5.98)$ \\
\hline Share of variance & 87.00 & 12.92 & 7.87 & 0.08 \\
\hline Statement $3 /$ & -- & 108.64 & 44.10 & -2.45 \\
\hline Standard error & -- & $(46.66)$ & (13.29) & $(1.93)$ \\
\hline Share of variance & 93.90 & 6.10 & 2.25 & 0.00 \\
\hline \multicolumn{5}{|c|}{$\begin{array}{l}\text { Source: IMF staff calculations. } \\
\text { 1/ Dec. 20, } 1991 \text { and July 2, } 1992 \text { for no statement; Jan. } 3 \text { and April 18, } 2001 \text { for statement. } \\
\text { 2/ The sample starts in } 1994 \text { for rate changes and in } 1999 \text { for non-action and inaction days. } \\
\text { 3/ The sample starts in February } 1994 \text { for all regressions. }\end{array}$} \\
\hline
\end{tabular}

maintained for a considerable period," serves as a good example. While the fourquarter eurodollar contract jumped 20 basis points, the current surprise was zero and expectations for the March meeting only ticked up one basis point.

- $\quad$ The decline in volatility on rate change days only appears when intermeeting changes are dropped from the recent sample. Statements have made no difference in the overall data, but the results excluding the two intermeeting moves mentioned above show a clear downward break in volatility since 1994, while there is not such a large impact on the variance in the earlier subsample by taking out its two largest surprises. This finding suggests that surprise actions via intermeeting moves have allowed the FOMC to retain leverage over short-term expectations, but that this channel has not been used frequently in the era of statements.

The bottom section of Table 3 looks at the variance in short-term monetary surprises in equations of the following form:

$s_{t}^{2}=\beta_{0}+\beta_{1}$ action $+\varepsilon_{t}$

where $s_{t}^{2}$ is the squared short-term surprise and action is defined as a dummy variable that takes a value of one if a rate change occurs and zero otherwise. A separate regression is also 


\begin{tabular}{|c|c|c|c|c|}
\hline \multicolumn{5}{|c|}{$\begin{array}{l}\text { Table 4. The Distribution of Daily Changes in the Expected } \\
\text { Federal Funds Rate After the Next FOMC Meeting }\end{array}$} \\
\hline & \multirow[t]{2}{*}{ Non-action } & \multicolumn{2}{|c|}{ Rate change } & \multirow[t]{2}{*}{ Inaction } \\
\hline & & All & $\begin{array}{l}\text { Excluding two } \\
\text { largest } \\
\text { outliers } 1 /\end{array}$ & \\
\hline \multicolumn{5}{|l|}{ Variance (in basis points) } \\
\hline No statement & 14.16 & 105.94 & 79.45 & 14.50 \\
\hline Statement $2 /$ & 7.36 & 81.02 & 53.11 & 2.69 \\
\hline \multicolumn{5}{|c|}{ Significance of change in variance } \\
\hline P-value of Brown-Forsythe tests & 0.00 & 0.33 & 0.05 & 0.00 \\
\hline \multicolumn{5}{|c|}{ Impact of FOMC actions on variance } \\
\hline No statement & -- & 183.60 & 145.37 & -3.18 \\
\hline Standard error & -- & $(53.47)$ & $(48.12)$ & $(4.45)$ \\
\hline Share of variance & 84.76 & 15.24 & 10.77 & 0.00 \\
\hline Statement $3 /$ & -- & 76.78 & 44.88 & -5.93 \\
\hline Standard error & -- & $(25.65)$ & $(14.04)$ & $(1.62)$ \\
\hline Share of variance & 95.54 & 4.43 & 1.84 & 0.03 \\
\hline \multicolumn{5}{|c|}{$\begin{array}{l}\text { Source: IMF staff calculations. } \\
\text { 1/ Dec. 20, } 1991 \text { and July 2, } 1992 \text { for no statement; Jan. } 3 \text { and April 18, } 2001 \text { for statement. } \\
\text { 2/ The sample starts in } 1994 \text { for rate changes and in } 1999 \text { for non-action and inaction days. } \\
\text { 3/ The sample starts in February } 1994 \text { for all regressions. }\end{array}$} \\
\hline
\end{tabular}

run where actions are defined as FOMC meetings where no rate change occurs. The coefficient $\beta_{1}$ can be interpreted as the impact of action days on the variance in the current month federal funds futures contract, in excess of the usual variance on non-FOMC days.

These regressions show that FOMC days when rates are changed have a significant impact on the variance of short-term surprises, but days when rates are held are no different than non-action days. For rate change days $\beta_{1}$ is always positive and highly significant, while for inaction days it is slightly negative. At the same time, looking at the R-squareds of the regressions, the share of variance accounted for by rate change days has fallen, as a larger share of actions have been anticipated by financial markets. Excess variance on rate change days has dropped by one half compared to the period before statements - to 6 percent of total variance from over 12 percent, and by two thirds when outliers are excluded. ${ }^{13}$

The introduction of statements would be expected to reduce timing surprises, as they could be used to telegraph near-term rate decisions. Although Gürkaynak (2005) and Gürkaynak, Sack, and Swanson (2007) show that the incidence of timing surprises has fallen over time,

\footnotetext{
${ }^{13}$ Strictly speaking, the share of variance accounted for by non-action days also includes volatility on FOMC days that is not over and above the usual level.
} 
which might bias the results toward finding a decline in short-term surprises in recent years, none of the above findings are affected by removing timing surprises from the measure. A timing surprise is defined as any part of the current surprise that is not expected to persist after the next FOMC meeting. For example, say markets expect an easing of 25 basis points at one of the next two meetings, with a 50/50 probability of the rate cut occurring at either meeting. If the cut occurs at the first meeting, but federal funds futures indicate that expected rates after the next meeting are unchanged, then the rate cut would show up in the current surprise measure as a $12 \frac{1}{2}$ basis points easing, but the entire move would be attributed to a timing surprise. Table 4 repeats the calculations in Table 3, only this time on data that removes the effects of pure timing surprises. ${ }^{14}$ However, the evidence for a decline in shortterm volatility on inaction days is even stronger, and there is a greater fall in the share of variance accounted for by excess variance on rate change days.

\section{Have Statements Provided Additional Information About the Future Path of Monetary Policy?}

This section calculates a measure of long-term monetary surprises - $l_{t}$ in equation (2) — and examines its behavior before and after the advent of statements. The working hypothesis is that realizations of $l_{t}$ should have grown larger because statements have increased the amount of information revealed on FOMC action dates concerning the future path of monetary policy_as distinct from the implications of short-term surprises for interest rates prevailing in the future..$^{15}$

\section{A. Calculating Long-Term Surprises}

Because $l_{t}$ is not directly observable, it needs to be estimated. Previous authors have used a variety of similar methods to obtain measures of long-term surprises from existing financial market instruments. Gürkaynak (2005) regresses the change in expected rates after the third meeting on the change after the second meeting and the timing surprise, calling the unexplained portion of the change the "slope" component of the surprise. Gürkaynak, Sack, and Swanson (2005) conduct a factor estimation of federal funds and eurodollar futures contracts extending out to one year and find that two factors are sufficient to explain the variation in monetary policy expectations at that horizon. The raw factors are then rotated so that one of the resulting factors represents only the component of the impact of FOMC decisions on one-year expectations not caused by surprises to the current target rate. Bernanke, Reinhart, and Sack (2004) and Gürkaynak, Sack, and Swanson (2007) both use Cholesky decompositions to extract surprise factors at different horizons.

\footnotetext{
${ }^{14}$ Expected rates after the next FOMC meeting are calculated using the methodology in Gürkaynak (2005).

${ }^{15}$ This is not to imply that statements can substitute for a target interest rate in the implementation of monetary policy. Rather, the statement sends a signal about the possible future path of the target rate, but the content of this information can differ from the measured surprise to the current policy rate.
} 


\begin{tabular}{|c|c|c|c|c|c|}
\hline \multicolumn{6}{|c|}{$\begin{array}{l}\text { Table 5. Correlation Between Changes in Current-Month Federal Funds and } \\
\text { Four-Quarter Eurodollar Futures }\end{array}$} \\
\hline & \multirow[t]{2}{*}{ Non-action } & \multirow[t]{2}{*}{ Actions } & \multicolumn{2}{|c|}{ Rate change } & \multirow[t]{2}{*}{ Inaction } \\
\hline & & & All & $\begin{array}{l}\text { Excluding } \\
\text { two largest } \\
\text { outliers } 1 /\end{array}$ & \\
\hline No statement & 0.55 & 0.71 & 0.76 & 0.85 & 0.29 \\
\hline Statement & 0.50 & 0.28 & 0.34 & 0.45 & -0.20 \\
\hline T-statistic on difference & 1.92 & 2.71 & 1.56 & 1.44 & 2.12 \\
\hline \multicolumn{6}{|c|}{ T-statistic (compared to Inaction correlation in same period) } \\
\hline No statement & 2.00 & 2.43 & 1.82 & 2.08 & -- \\
\hline Statement & 3.65 & 2.15 & 2.26 & 2.67 & -- \\
\hline $\begin{array}{l}\text { Source: IMF staff calcula } \\
\text { Note: T-statistics in bold } \\
\text { 1/ Dec. 20,1991 and Jul }\end{array}$ & $\begin{array}{l}\text { is are signi } \\
\text { no stateme }\end{array}$ & $\begin{array}{l}\text { th at th } \\
\text { an. } 3 \text { a }\end{array}$ & 18, & $\begin{array}{l}\text { levels, res } \\
\text { or stateme }\end{array}$ & ively. \\
\hline
\end{tabular}

The common feature of the above analyses is that they rely on the average correlation between movements in short-term and long-term interest rate futures over a long sample to attribute the change in long-term interest rate expectations to its various components. This approach relies on two assumptions - that the correlations have been stable over time, and that they are the same on rate change days as on inaction days.

Both these assumptions are rejected in Table 5, which presents correlations between the short-term monetary surprise and the change in the four-quarter eurodollar futures rate. It also reports T-statistics on the difference in the correlation over the periods with and without statements, and across types of FOMC action within each period. Since the introduction of statements, there has been a significant decline in the correlation on inaction days and on all action days taken together, while the drop in correlation on rate change days narrowly misses significance. ${ }^{16}$ The correlation between the responses of federal funds and eurodollar futures is significantly different on inaction days than on other days, both before and after statements.

This paper uses a more direct, arithmetic approach to estimating long-term monetary surprises. They are calculated as the change in the four-quarter eurodollar futures rate minus the short-term surprise, for which the change in expected rates after the next FOMC meeting in the future is used. This prevents timing surprises from distorting the measured long-term surprise. The instrument underlying the eurodollar futures contract is the 90-day London Interbank Offer Rate (LIBOR) prevailing at the time of the contract's expiration. LIBOR is tied closely to the federal funds rate because they are both rates paid on short-term loans

\footnotetext{
${ }^{16}$ This is likely due to the low number of observations in the no statement category, as the magnitude of the decline in the correlation is similar to those in the action and inaction columns, which have more observations.
} 
between financial institutions with high credit ratings. Because the eurodollar futures rate is a forward interest rate, not a yield, it gives a direct reading of expectations of short-term rates one year ahead, so no forward rate conversion needs to be calculated. The eurodollar futures market is highly liquid, as Rigobon and Sack (2004) find that their response to monetary policy innovations is on par with that of Treasury yields. The one-year future has been an accurate predictor of the course of monetary policy over that horizon (Gürkaynak, Sack, and Swanson 2007), and is analyzed by all the other works that look at long-term monetary policy expectations,

Since the current meeting's surprise has previously been defined as $s_{t}$, the long-term surprise can be expressed as:

$l_{t}=\Delta e d 4-s_{t}-$ timing

The long-term surprise, $l_{t}$, can be thought of as the component of the change in the fourquarter eurodollar futures rate, $e d 4$, that is not caused by short-term factors. The advantage of the approach based on factor decompositions or regressions is that it eliminates the correlation between the factors and thus eases the interpretation of results of regressions of changes in asset prices on the factors. However, the correlation between $s_{t}$ and $l_{t}$ using the arithmetic method is low enough-less than -0.1 for the full sample and period before statements, and -0.3 since May 1999 - that multicollinearity between the regressors is not a problem. Furthermore, in a comparison of long-term surprises obtained using regressions as in Gürkaynak (2005) with those calculated from equation (6), the results from the regression approach yield some counterintuitive results when the timing surprise is relatively large or the surprise in expected rates for the second FOMC meeting exceeds the change in the eurodollar futures contract. The results from the arithmetic method show no such anomalies.

\section{B. The Impact of Statements on Long-Term Surprises}

Figure 2 presents long-term monetary surprises by action date. The impact of statements on the magnitude of surprises is visually most apparent in 1994 and from 2001 to early 2004or when market uncertainty about interest rates is at its highest. This contrasts with the lower volatility in long-term surprises during the 1990-91 recession, before statements, despite sizable short-term surprises and high levels of long-term uncertainty by other measures. ${ }^{17}$

Table 6 presents the variance in long-term monetary policy surprises by period and type of action. ${ }^{18}$ There is a clear and statistically significant break in variance for both rate change

\footnotetext{
${ }^{17}$ See Swanson (2006) for some evidence on uncertainty about interest rates.

${ }^{18}$ Excluding the two intermeeting changes from the statement period and the two largest outliers from the prestatement period did not affect the significance of the results.
} 
Figure 2. Long-Term Monetary Policy Surprises, July 1989-2007
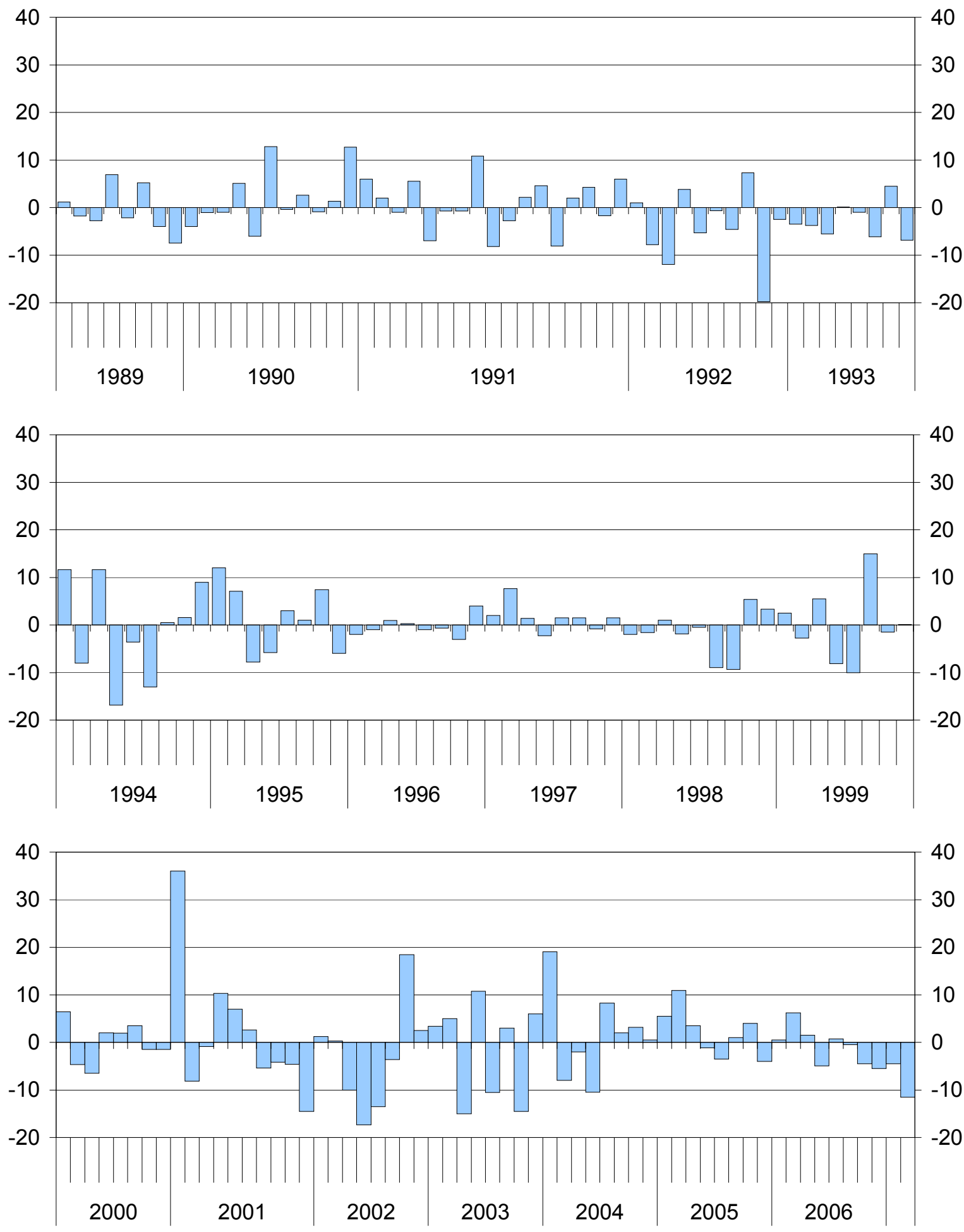

Source: IMF staff calculations. 


\begin{tabular}{|c|c|c|c|}
\hline \multicolumn{4}{|c|}{$\begin{array}{l}\text { Table 6. The Distribution of Daily Changes in } \\
\text { Long-Term Monetary Surprises }\end{array}$} \\
\hline & Non-action & Rate change & Inaction \\
\hline \multicolumn{4}{|l|}{ Variance (in basis points) } \\
\hline No statement & 29.40 & 34.42 & 25.39 \\
\hline Statement (since Feb. 4, 1994) & -- & 88.49 & -- \\
\hline Statement (since May. 18, 1999) & 29.53 & 86.38 & 68.23 \\
\hline \multicolumn{4}{|c|}{ Significance of change in variance } \\
\hline \multicolumn{4}{|c|}{$P$-value of Brown-Forsythe tests } \\
\hline Statements since 1994 & -- & 0.07 & -- \\
\hline Statements since 1999 & 0.62 & 0.21 & 0.03 \\
\hline \multicolumn{4}{|c|}{ Distribution relative to non-action days } \\
\hline \multicolumn{4}{|l|}{$P$-value of Brown-Forsythe tests } \\
\hline No statement & -- & 0.65 & 0.00 \\
\hline Statements since 1999 & -- & 0.00 & 0.00 \\
\hline \multicolumn{4}{|c|}{ Impact of FOMC actions on variance } \\
\hline \multicolumn{4}{|c|}{ OLS regressions of squared daily change on dummy variables } \\
\hline No statement & -- & -1.76 & 3.10 \\
\hline Standard error & -- & $(9.10)$ & $(13.38)$ \\
\hline Share of variance & 100.00 & 0.00 & 0.00 \\
\hline Statements since 1999 & -- & 55.49 & 38.66 \\
\hline Standard error & -- & (36.78) & $(17.67)$ \\
\hline Share of variance & 98.51 & 1.04 & 0.45 \\
\hline
\end{tabular}

days and inaction days since the introduction of statements, while the variance for non-action days has not changed. ${ }^{19}$ Table 6 also compares long-term surprises across types of FOMC days. In the period before statements, the variance in long-term monetary surprises on action days was the same as or lower than on non-action days. Since statements, however, longterm surprises on all FOMC days have been significantly higher than on non-action days.

The bottom section of Table 6 shows that FOMC days have only contributed to the variance in long-term surprises since the introduction of statements. Before statements, the impact of FOMC days on $l_{t}$ was no different than any other day. Movements in $l_{t}$ were caused entirely by economic data releases or other developments. There is no evidence that monetary policy shocks affected interest rates by any other means than through surprises to current rates and their implications for the target interest rate in the future. Without statements, information about monetary policy was largely transmitted through effects on $s_{t}$.

\footnotetext{
${ }^{19}$ The change in variance for rate change days is only significant since 1994, despite the same variance in longterm surprises since 1999, indicating that the small number of observations since 1999 is affecting the results.
} 


\begin{tabular}{|c|c|c|c|c|}
\hline \multicolumn{5}{|c|}{$\begin{array}{l}\text { Table } 7 . \text { The Distribution of Daily Changes in } \\
\text { Four-Quarter Eurodollar Futures }\end{array}$} \\
\hline & Non-action & Action & Rate change & Inaction \\
\hline \multicolumn{5}{|l|}{ Variance (in basis points) } \\
\hline No statement & 51.61 & 109.25 & 137.81 & 36.87 \\
\hline Statement (since May. 18, 1999) & 46.23 & 87.42 & 94.38 & 81.83 \\
\hline \multicolumn{5}{|c|}{ Significance of change in variance } \\
\hline \multicolumn{5}{|l|}{$P$-value of Brown-Forsythe tests } \\
\hline Statements since 1999 & 0.91 & 0.96 & 0.12 & 0.03 \\
\hline \multicolumn{5}{|c|}{ Impact of FOMC actions on variance } \\
\hline \multicolumn{5}{|c|}{ OLS regressions of squared daily change on dummy variables } \\
\hline No statement & -- & -- & 182.91 & -7.58 \\
\hline Standard error & -- & -- & (76.94) & $(12.72)$ \\
\hline Share of variance & 96.24 & 3.76 & 3.76 & 0.00 \\
\hline Statements since 1999 & -- & -- & 34.76 & 36.75 \\
\hline Standard error & -- & -- & (17.87) & $(21.79)$ \\
\hline Share of variance & 99.58 & 0.42 & 0.21 & 0.21 \\
\hline
\end{tabular}

\section{Which Effect Predominates?}

The introduction of monetary policy statements has seen a decline in short-term surprises and an increase in long-term surprises. What has been the net effect on financial market fluctuations? The four-quarter eurodollar futures contract is an ideal candidate for analysis, as it should pick up an impact from both short- and long-term surprises, while not being dominated by either:

$$
\Delta e d 4=f\left(s_{t}, l_{t}\right)
$$

The change in the short-term interest rate expected to prevail in one year is a function of shocks to current policy (and how long those shocks are expected to persist) and shifts in long-term expectations not caused by surprises in the current target rate.

Table 7 applies to the raw four-quarter eurodollar futures rate the same tests that were performed on monetary surprises. On inaction days, the increased volatility in $l_{t}$ has outweighed the reduction in $s_{t}$, while the reduced variance on rate change days has fallen short of statistical significance. Overall, volatility on action days has fallen, but the difference since statements is not statistically significant. The bottom section of Table 7 shows that there has also been a slight decline in the share of the variance in eurodollar futures accounted for by excess volatility on FOMC days. The driving factor could be either the reduction in current surprises or a decline in the market's view on their persistence. While the evidence is not strongly persuasive, it appears that statements have dampened fluctuations in long-term interest rates on FOMC days, despite their role as an additional channel through which to communicate news about monetary policy. 


\begin{tabular}{|c|c|c|c|c|c|c|c|c|}
\hline \multirow[b]{2}{*}{ Maturity } & \multicolumn{4}{|c|}{ Before February 1994} & \multicolumn{4}{|c|}{ After March 1999} \\
\hline & Timing & Short-term & Long-term & $\mathrm{R}^{2}$ & Timing & Short-term & Long-term & $\mathrm{R}^{2}$ \\
\hline 3 month & $\begin{array}{l}39.0^{* *} \\
(9.0)\end{array}$ & $\begin{array}{l}87.4^{* *} \\
(6.6)\end{array}$ & $\begin{array}{l}15.8^{* *} \\
(5.4)\end{array}$ & 0.85 & $\begin{array}{l}12.8 \\
(8.9)\end{array}$ & $\begin{array}{l}71.3^{* *} \\
(6.4)\end{array}$ & $\begin{array}{r}7.3 \\
(4.7)\end{array}$ & 0.76 \\
\hline 6 month & $\begin{array}{l}42.5^{* *} \\
(7.5)\end{array}$ & $\begin{array}{l}88.9^{* *} \\
(5.1)\end{array}$ & $\begin{array}{l}18.3^{\text {** }} \\
(4.5)\end{array}$ & 0.91 & $\begin{array}{l}10.6 \\
(5.7)\end{array}$ & $\begin{array}{l}73.9^{* *} \\
(4.0)\end{array}$ & $\begin{array}{l}24.5^{\text {** }} \\
(3.9)\end{array}$ & 0.84 \\
\hline 12 month & $\begin{array}{l}39.8^{* *} \\
(7.3)\end{array}$ & $\begin{array}{l}91.5 \text { ** } \\
(4.6)\end{array}$ & $\begin{array}{l}24.8^{* *} \\
(5.1)\end{array}$ & 0.92 & $\begin{array}{l}19.0 \text { * } \\
(8.3)\end{array}$ & $\begin{array}{l}69.8^{* *} \\
(3.1)\end{array}$ & $\begin{array}{l}41.1^{\text {** }} \\
(3.3)\end{array}$ & 0.86 \\
\hline 2 year & $\begin{array}{r}15.0 \\
(12.2)\end{array}$ & $\begin{array}{l}80.7^{* *} \\
(6.4)\end{array}$ & $\begin{array}{l}66.2 \text { ** } \\
(11.8)\end{array}$ & 0.76 & $\begin{array}{r}3.1 \\
(7.0)\end{array}$ & $\begin{array}{l}83.2^{* *} \\
(5.4)\end{array}$ & $\begin{array}{l}72.7^{\text {** }} \\
(5.0)\end{array}$ & 0.88 \\
\hline 5 year & $\begin{array}{r}-9.2 \\
(9.3)\end{array}$ & $\begin{array}{l}62.1^{\text {** }} \\
(7.2)\end{array}$ & $\begin{array}{c}76.3^{* *} \\
(10.6)\end{array}$ & 0.77 & $\begin{array}{r}0.2 \\
(15.3)\end{array}$ & $\begin{array}{l}54.8^{* *} \\
(9.5)\end{array}$ & $\begin{array}{l}79.3^{\text {** }} \\
(7.8)\end{array}$ & 0.77 \\
\hline 10 year & $\begin{array}{r}-16.1 \\
(8.7)\end{array}$ & $\begin{array}{l}42.3^{* *} \\
(8.1)\end{array}$ & $\begin{array}{l}73.1^{* *} \\
(10.3)\end{array}$ & 0.69 & $\begin{array}{r}6.1 \\
(15.5)\end{array}$ & $\begin{array}{l}32.1^{* *} \\
(12.0)\end{array}$ & $\begin{array}{l}64.6^{* *} \\
(9.4)\end{array}$ & 0.60 \\
\hline 30 year & $\begin{array}{r}-15.5 \\
(9.2)\end{array}$ & $\begin{array}{l}32.0 \text { ** } \\
(7.7)\end{array}$ & $\begin{array}{l}56.3^{* *} \\
(9.7)\end{array}$ & 0.57 & $\begin{array}{r}7.9 \\
(15.1)\end{array}$ & $\begin{array}{l}12.8 \\
(9.1)\end{array}$ & $\begin{array}{l}40.8^{* *} \\
(7.9)\end{array}$ & 0.35 \\
\hline
\end{tabular}

\section{HAVE STATEMENTS LED TO AN INCREASED ROLE FOR LONG-TERM SURPRISES IN EXPLAINING INTEREST RATE MOVEMENTS?}

This section looks at the role of changes in monetary policy expectations in determining interest rates. It has already been established that statements increase the variance in longterm expectations and decrease that of short-term expectations. In weighing the response of long-term rates to policy expectations, then, movements in long-term expectations on FOMC days would become of increasing importance in determining long-run rates even if the per unit response of interest rates to expectations doesn't change.

Table 8 shows the response of Treasury securities at various horizons to the different components of monetary policy surprises on FOMC days - the timing surprise, the change in expected rates after the next FOMC meeting, and the long-term surprise, calculated as in the previous sections. The left-hand panel shows the estimated responses for July 1989 to December 1993 and the right-hand panel covers May 1999 to March 2007. Coefficients in bold italics are significantly different at the five percent level pre- and post-statements, indicating the maturities for which statements have had an impact on yields above and beyond their effects via the composition and magnitude of surprises. ${ }^{20}$ The regressions explain roughly 60 to 90 percent of the variation in Treasury yields on FOMC days and,

\footnotetext{
${ }^{20}$ Estimation on the entire July 1989 to March 2007 period using dummies for meetings with statements yielded quite similar results.
} 


\begin{tabular}{|c|c|c|c|c|}
\hline \multirow[b]{2}{*}{ Maturity } & \multicolumn{2}{|c|}{ Marginal $\mathrm{R}^{2}$ of Long-term } & \multicolumn{2}{|c|}{ Marginal $R^{2}$ of Long-term as Share of Total $R^{2}$} \\
\hline & Before February 1994 & After March 1999 & Before February 1994 & After March 1999 \\
\hline 3 month & 0.01 & 0.01 & 1.07 & 0.99 \\
\hline 6 month & 0.01 & 0.13 & 1.59 & 15.89 \\
\hline 12 month & 0.03 & 0.36 & 2.93 & 42.08 \\
\hline 2 year & 0.18 & 0.54 & 23.66 & 61.82 \\
\hline 5 year & 0.33 & 0.60 & 42.79 & 77.87 \\
\hline 10 year & 0.42 & 0.51 & 61.29 & 84.88 \\
\hline 30 year & 0.36 & 0.32 & 62.15 & 91.30 \\
\hline
\end{tabular}

despite the different methodology in calculating long-term surprises, the results are in line with the findings in Gürkaynak, Sack, and Swanson (2005) and Gürkaynak (2005):

- $\quad$ Short-term surprises are the most important factor for yields out to one year, but their impact declines for longer-dated securities. The short-term surprise appears to typically induce a long-lasting, level shift in rates, affecting yields at all maturities. This confirms the finding in Cook and Hahn (1989) and Kuttner (2001) that there is little differentiation in the impact of the current policy surprise on yields of various maturities out to one year. The response to timing surprises is similar, though smaller in magnitude.

- Long-term surprises are now the predominant factor in determining yields of more than two years. Given the definition of long-term surprises as that part of the one-year shock that is not explained by the short-term surprise, it is not surprising that they affect securities of less than one year maturity, as the impact of the short-term shock can begin to fade in as little as six weeks.

- $\quad$ The main impact of statements on long-term yields is through their effects on the mix of short- and long-term surprises. The coefficients on timing and short-term surprises are generally smaller since statements, with the differences statistically significant for maturities of one year or less. Statements appear to have led to diminished uncertainty about the implications of timing surprises for future monetary policy, and thus yields. For long-term surprises, the coefficients are higher from six months through five years - if markets see statements as credible about the future direction of monetary policy, then, for a given long-term surprise, the market reaction could be larger. However, the only significant increase is at one year, so there is little evidence that statements have changed the per-unit impact of long-term surprises on yields.

The contribution of long-term surprises on FOMC days to changes in Treasury yields at various maturities has increased sharply since the advent of statements. The first two columns of Table 9 show the change in adjusted r-squared when adding the long-term 
surprise to regressions including only the timing and short-term surprises. The third and fourth columns report the same measure as a share of the total $r$-squared values from Table 8 . The importance of long-term surprises has risen - through gains in the marginal r-squared for yields from six months to five years and through an increased share of the total r-squared accounted for by long-term surprises at all maturities.

\section{Conclusions}

This paper illustrates the importance of central bank communication by showing that FOMC statements have been associated with significant differences in the magnitude and composition of changes to monetary policy expectations. Under a theoretical framework in which the information transmitted from the Federal Reserve to financial markets on FOMC days is broken down into its relevance for the short- or long-term, there are several empirical implications of the impact of statements: 1) the variance of long-term monetary surprises should increase; 2) a lower proportion of the variance in long-term surprises should occur outside of FOMC days; 3 ) the variance of short-term monetary surprises, should decline; 4) a higher proportion of the variance in short-term surprises should occur outside of FOMC days; and 5) long-term monetary surprises should take on greater importance in explaining movements in interest rates, with a reduced role for short-term surprises.

The evidence is strongly in favor of all five of the above implications. In particular, there is a sharp reduction in the variance of short-term monetary surprises since the introduction of statements, and the share of their total variance accounted for by excess variance on FOMC days is cut by more than half. By contrast, the variance of long-term monetary surprises has increased, and the role of FOMC days in explaining the total daily variance, though small, has risen. These effects are present both on days when the federal funds rate is changed and when the FOMC meets but takes no action, which indicates that statements, and not movements in the policy instrument itself, are the cause. The role of long-term surprises in determining market interest rates has also risen with the advent of statements, as seen in the greater variance of long-term surprises, in some reduction of the per unit response of yields to short-term surprises, and in the increased explanatory power of long-term surprises for market interest rates.

The presence of all these effects attests to the credibility the FOMC has with financial markets. It seems that, when statements reveal information about the future path of policy, markets have believed that the FOMC can and will act in a manner consistent with this information. Of course, while this particular change in communication strategy has increased monetary and economic stability, the question of how much communication is optimal remains open to further analysis (Mackie et al, 2007; Kohn, 2005). Another interesting avenue for future research would be to examine the effects that shifts in the communication strategies of central banks in other countries have had on the response of asset prices to monetary policy, and relate any differences from these results to central bank credibility or structural features of the financial market. 


\section{References}

Bernanke, B., and K. Kuttner, 2005, "What Explains the Stock Market's Reaction to Federal Reserve Policy?” The Journal of Finance, Vol. 60, No. 3, pp. 1221-1257.

, V. Reinhart, and B. Sack, 2004, "Monetary Policy Alternatives at the Zero Bound: An Empirical Assessment," Brookings Papers on Economic Activity, 2004 No. 2, pp. 1-100.

Bomfim, A., 2003, "Pre-announcement Effects, News Effects, and Volatility: Monetary Policy and the Stock Market," Journal of Banking and Finance, Vol. 27, No. 1, pp. 133-151.

Brown, M., and A. Forsythe, 1974, "Robust Tests for the Equality of Variances," Journal of the American Statistical Association, Vol. 69., No. 346, pp. 364-367.

Fatum, R., and B. Scholnick, 2006, "Do Exchange Rates Respond to Day-to-Day Changes in Monetary Policy Expectations When No Monetary Policy Changes Occur?” Journal of Money, Credit, and Banking, Vol. 38, No. 6, pp. 1641-1657.

Faust, J., E. Swanson, and J. Wright, 2004, "Identifying VARS Based on High Frequency Futures Data," Journal of Monetary Economics, Vol. 51, pp. 1107-1131.

_ , J. Rogers, S. Wang, and J. Wright, 2007, “The High-Frequency Response of Interest Rates to Macroeconomic Announcements," Journal of Monetary Economics, Vol. 54, pp. 1051-1068.

Gürkaynak, R., 2005, “Using Federal Funds Futures Contracts for Monetary Policy Analysis," Board of Governors of the Federal Reserve System, Finance and Economics Discussion Series, Working Paper \#2005-29 (Washington).

B. Sack, and E. Swanson, 2005, "Do Actions Speak Louder Than Words? The Response of Asset Prices to Monetary Policy Actions and Statements," International Journal of Central Banking, Vol. 1, No. 1, pp. 55-93.

$\longrightarrow, \ldots$, and $— 2007$, "Market-Based Measures of Monetary Policy Expectations," Journal of Business and Economic Statistics, Vol. 25, No. 2, pp. 201-212.

Hamilton, J., 2007, "Daily Changes in Fed Funds Futures Prices," Working paper. Available on the internet: http://dss.ucsd.edu/ jhamilto/daily ff.pdf

Kohn, D., and B. Sack, 2003, “Central Bank Talk: Does it Matter and Why?” Board of Governors of the Federal Reserve System, Finance and Economics Discussion Series, Working Paper \#2003-55 (Washington).

-, "Central Bank Communication," remarks at the annual meeting of the American Economics Association, Philadelphia, January 9, 2005.

Krueger, J., and Kuttner, K., 1996, "The Fed Funds Future Rate as a Predictor of Federal Reserve Policy," Journal of Futures Markets, Vol. 16, No. 8, pp. 865-879. 
Kuttner, K., 2001, "Monetary Policy Surprises and Interest Rates: Evidence from the Fed Funds Futures Market," Journal of Monetary Economics, Vol. 47, pp. 523-544.

Lange, J., Sack, B., and W. Whitesell, 2003, “Anticipations of Monetary Policy in Financial Markets,” Journal of Money, Credit, and Banking, Vol. 35, No. 6, pp. 889-909.

Mackie, D., G. Cooper, V. Papakos, N. Mai, and M. Barr, 2007, “Central Bank Communication Hits Diminishing Marginal Returns,” JPMorgan Research, London, May 11.

Piazzesi, M., and E. Swanson, 2006, "Futures Prices as Risk-Adjusted Forecasts of Monetary Policy," Federal Reserve Bank of San Francisco Working Paper 2006-23.

Rigobon, R., and B. Sack, 2003, "Measuring the Reaction of Monetary Policy to the Stock Market," Quarterly Journal of Economics, Vol. 118, No. 2, pp. 639-669.

Poole, W., Rasche, R., and D. Thornton, 2002, "Market Anticipations of Monetary Policy Actions," Federal Reserve Bank of St. Louis Review, July/August, pp. 65-94.

, and - 2004, “The Impact of Monetary Policy on Asset Prices," Journal of Monetary Economics, Vol. 51, pp. 1553-1575.

Roley, V., and G. Sellon, 1995, "Monetary Policy Actions and Long-Term Interest Rates," Federal Reserve Bank of Kansas City Economic Review, Fourth Quarter, pp. 73-89.

Rudebusch, G., 2002, "Term Structure Evidence on Interest Rate Smoothing and Monetary Policy Inertia,” Journal of Monetary Economics, Vol. 49, pp. 1161-1187.

, 2006, “Monetary Policy Inertia: Fact or Fiction?” International Journal of Central Banking, Vol. 2, No. 4, pp. 85-135.

Swanson, E., 2006, "Have Increases in Federal Reserve Transparency Improved Private Sector Interest Rate Forecasts?" Journal of Money, Credit, and Banking, Vol. 38, No. 3, pp. 791-819. 